DOCUMENTA

\title{
"QUINHENTOS ANOS DE CONTATO": POR UMA TEORIA ETNOGRÁFICA DA (CONTRA) MESTIÇAGEM
}

Marcio Goldman

\section{Apresentação}

É com muita satisfação que publicamos na seção Documenta de Mana a conferência proferida pelo Prof. Marcio Goldman durante seu concurso para Professor Titular do Departamento de Antropologia do Museu Nacional/UFRJ.

A conferência teve lugar no Museu Nacional, no dia 16 de março de 2015, diante da banca examinadora formada pelos professores Otávio Velho, Gemma Orobitg, José Carlos Rodrigues, Pedro Pitarch e Sylvia Caiuby e de uma audiência de colegas, alunos, ex-alunos e muitos outros interessados.

Nela, o autor opta por explorar o que denomina provisoriamente de "relação afroindígena", termo usado para designar os agenciamentos entre afrodescendentes e indígenas no continente americano. Apresentando o que o autor chama de "um caráter incerto e aberto", a conferência oferece-nos a possibilidade de acompanhar o momento de amadurecimento dessa reflexão ainda em curso, não deixando de registrar o quanto ela se ancora em sólida e longa trajetória de pesquisa, formação e orientação. Densidade etnográfica e teórica combinam-se, desse modo, com vivacidade em um texto que coloca sob desconfiança as sínteses e as reduções. Como destaca Goldman, pensar sobre a relação afroindígena é pensar sobre uma relação com "alto potencial de desestabilização do nosso pensamento e que, por isso mesmo, deve estar no coração de uma antropologia que encara as diferenças, que leva a sério o que as pessoas pensam, que é capaz de se manter afastada dos clichês que nos assolam e, assim, pensar diferente". 
O texto que se segue possui, ainda, um caráter incerto e aberto, uma vez que diz respeito a um tema com o qual comecei a trabalhar apenas recentemente e que denominei, provisoriamente, de "relação afroindígena" (sem hífen - ver Goldman 2015) - em poucas palavras, os agenciamentos entre afrodescendentes e ameríndios. Tema que certamente deriva de meu campo empírico de investigação, o candomblé de nação angola, com seus infindáveis debates sobre origens e sincretismos, mas que aparecerá apenas no início da apresentação.

Após algumas observações iniciais e a apresentação algo abstrata da questão da relação afroindígena, procurarei extrair algumas conclusões provisórias a partir da justaposição de dois casos etnográficos específicos. O objetivo é começar a testar a possibilidade de pensar essa relação aplicando a ela o que Bruno Latour denominou princípio de irredução: não reduzi-la de antemão a uma pura questão identitária; e, ao mesmo tempo, não negar a priori que a identidade possa ser uma dimensão do fenômeno. Trata-se, basicamente, de pensar a relação afroindígena de um modo que não a reduza a simples reação à dominação branca, nem à mera oposição entre duas identidades — não importa se tidas como "primordiais" ou como constituídas por "contraste". Ao contrário, trata-se de pensar essa relação a partir das alteridades imanentes que cada coletivo comporta e que devem ser relacionadas com as alteridades imanentes de outros coletivos, traçando espaços de interseção em que as chamadas relações interétnicas não são redutíveis nem à ignorância recíproca, nem à violência aberta, e nem à fusão homogeneizadora (ver Losonczy 1997).

Começo com a lembrança de um estranho conto de Jorge Luis Borges, intitulado "O atroz redentor Lazarus Morell", no qual o autor assinala, de modo irônico, um dos paradoxos que marcam a invasão do futuro continente americano pelos europeus:

Em 1517, o padre Bartolomé de las Casas compadeceu-se dos índios que se extenuavam nos laboriosos infernos das minas de ouro antilhanas, e propôs ao imperador Carlos V a importação de negros, que se extenuassem nos laboriosos infernos das minas de ouro antilhanas. A essa curiosa variação de um filantropo devemos infinitos fatos: os blues de Handy, o sucesso alcançado em Paris pelo pintor-doutor uruguaio D. Pedro Figari, a boa prosa agreste do também oriental D. Vicente Rossi, a dimensão mitológica de Abraham Lincoln, os quinhentos mil mortos da Guerra da Secessão, os três mil e trezentos milhões gastos em pensões militares, a estátua do imaginário Falucho, a admissão do verbo linchar na décima terceira edição do Dicionário da Academia Espanhola, o impetuoso filme Aleluya, a fornida carga de baionetas levada por Soler à frente de seus 
Pardos y Morenos em Cerrito, a graça da senhorita de Tal, o negro que assassinou Martín Fierro, a deplorável rumba El Manisero, o napoleonismo embargado e encarcerado de Toussaint Louverture, a cruz e a serpente no Haiti, o sangue das cabras degoladas pelo machado dos papaloi, a habanera mãe do tango, o candombe. Além disso: a culpável e magnífica existência do atroz redentor Lazarus Morell (Borges 1974:295).

A isso, conclui Borges, devemos "infinitos fatos", dos "quinhentos mil mortos da Guerra da Secessão", da "admissão do verbo linchar na décima terceira edição do Dicionário da Academia Espanhola", dos "três mil e trezentos milhões gastos em pensões militares", aos "blues de Handy"; "a habanera mãe do tango"; "o candombe"; "a graça de algumas senhoritas"; "a cruz e a serpente no Haiti"; "o sangue das cabras degoladas pelo machado dos papaloi".

De forma sem dúvida menos irônica que Borges, e sem qualquer referência ao universo indígena, o mesmo ponto também foi levantado por Félix Guattari ao falar do jazz, que:

Nasceu de um mergulho caósmico, catastrófico, que foi a escravização das populações negras nos continentes norte e sul-americano. E, depois, houve uma conjunção de ritmos, de linhas melódicas, com o imaginário religioso do cristianismo, com dimensões residuais do imaginário das etnias africanas, com um novo tipo de instrumentação, com um novo tipo de socialização no próprio seio da escravidão e, em seguida, com encontros intersubjetivos com as músicas folk brancas que estavam por lá; houve, então, uma espécie de recomposição dos territórios existenciais e subjetivos no seio dos quais não só se afirmou uma subjetividade de resistência por parte dos negros, mas que, além do mais, abriu linhas de potencialidade para toda a história da música (Guattari 1993:120).

Ora, como o jazz, o blues, a habanera e o candombe, as religiões de matriz africana — tema com o qual trabalho há quase quarenta anos — são um dos resultados desse criativo processo de reterritorialização que se seguiu à brutal desterritorialização de milhões de pessoas no movimento de origem do capitalismo com a exploração das Américas pela utilização do trabalho escravo. Em face dessa experiência mortal, articularam-se agenciamentos que combinaram, por um lado, dimensões de diferentes pensamentos de origem africana com aspectos dos imaginários religiosos cristãos e do pensamento ameríndio e, por outro, formas de organização social tornadas inviáveis pela escravização com todas aquelas que puderam ser utilizadas, dando origem a novas formas cognitivas, perceptivas, afetivas e organizacionais. Tratou-se, 
assim, de uma recomposição, em novas bases, de territórios existenciais aparentemente perdidos, do desenvolvimento de subjetividades ligadas a uma resistência às forças dominantes que nunca deixaram de tentar sua eliminação e/ou captura.

Pedindo perdão pela obviedade, a expressão "religiões de matriz africana" designa, pois, de forma algo grosseira, um conjunto heteróclito, mas articulado, de práticas e concepções religiosas cujas linhas de força principais foram trazidas pelos escravos africanos para as Américas. Provavelmente formadas ao longo do século XIX, essas religiões, como as conhecemos hoje, incorporaram, assim, ao longo de sua história, em maior ou menor grau, elementos das cosmologias e das práticas indígenas, do catolicismo popular e do espiritismo de origem europeia. Esses elementos foram se transformando na medida em que iam sendo combinados e foram sendo combinados na medida em que se transformavam, gerando uma infinidade de variantes religiosas muito parecidas quando olhadas de uma certa distância e bem diferentes quando olhadas de outra. Pode-se, assim, observar uma bem marcada diversidade entre os diferentes grupos de culto, diversidade ligada à região da África de onde provém a maior parte do repertório de cada grupo, assim como às modalidades e intensidades de suas conexões tidas por "sincréticas" com outras tradições religiosas. Meu trabalho etnográfico diz respeito a uma dessas variantes, o candomblé, mais especificamente um terreiro de nação angola, situado na cidade de Ilhéus, no sul do estado da Bahia, no nordeste brasileiro. Não obstante, acredito que o que tentarei dizer aqui também seja válido para outros casos, ainda que com o custo de algumas transformações.

O processo histórico de constituição dessas religiões parece explicar, ao menos em parte, o fato de serem ininterruptamente atravessadas por um duplo sistema de forças: centrípetas, codificando e unificando os cultos; centrífugas, fazendo pluralizar as variantes, acentuando suas diferenças e engendrando linhas divergentes. Mas o ponto fundamental é que essas forças estão sempre em coexistência e que elas não podem ser dispostas segundo um esquema histórico linear indo da unificação à desagregação ou desta para a primeira. A insistência em distribuir pela história forças sempre em coexistência costuma redundar em uma vã tentativa de apagar contradições aparentes, mas acaba, na verdade, apagando a heterogeneidade constitutiva do sistema.

É também em função dessa dualidade de forças que prefiro empregar a fórmula "religiões de matriz africana no Brasil" em lugar das tradicionais expressões "religiões africanas no Brasil", "religiões afro-brasileiras" ou, pior, "cultos afro-brasileiros". Isto porque o termo "matriz" tem a vantagem 
de poder ser entendido, simultaneamente, em seu sentido de algo que "dá origem a alguma coisa" - o que respeita, além de utilizar, o uso nativo, sempre preocupado em relacionar essas religiões com uma África que não acredito ser nem real, nem imaginária, nem simbólica, mas dotada de um sentido existencial - e em seu sentido matemático ou topológico ("matriz de transformações"), que aponta para o tipo de relação que acredito existir entre as diferentes atualizações dessas religiões e, ao mesmo tempo, para o método transformacional que penso necessário para seu tratamento analítico.

Retornemos, contudo, às observações de Borges e de Guattari. De fato, e ainda que os números sejam algo controversos, não é nada improvável que ao longo de cerca de 300 anos quase 10 milhões de pessoas tenham sido embarcadas à força da África para as Américas, na maior migração transoceânica da história. O ponto que eu gostaria de sublinhar aqui é que os cerca de 4 milhões de pessoas que podem ter chegado ao que hoje chamamos de Brasil encontraram milhões de indígenas, vítimas de um genocídio paralelo à diáspora africana, processos que, nunca é demasiado lembrar, sustentam a constituição desse mundo chamado de moderno. É nessa história, que é a de todos nós, que coexistem os poderes mortais da aniquilação e as potências vitais da criatividade.

Nesse sentido, aquilo que eu gostaria de explorar tentativamente aquio encontro entre afros e indígenas nas Américas - é o resultado do maior processo de desterritorialização e reterritorialização da história da humanidade, e é bastante notável que um fenômeno dessa envergadura tenha recebido relativamente tão pouca atenção, ou que tenha recebido um tipo de atenção que desconsidera completamente o que eu chamaria de dimensão transcendental desse encontro.

Como já observava Roger Bastide em 1973, "os antropólogos se interessaram sobretudo pelos fenômenos de adaptação dos candomblés africanos à sociedade dos brancos e à cultura luso-católica" (Bastide 1976:32). O que quer dizer, por um lado, que não se escreveu tanto assim sobre o que Bastide chamava de "encontro e casamento dos deuses africanos e dos espíritos indígenas no Brasil". Mas quer dizer sobretudo que aquilo que foi escrito, em geral, o foi a partir de um ponto de vista que subordinava a relação afroindígena a um terceiro elemento que estruturava o campo de investigação na mesma medida em que dominava o campo sociopolítico: o "branco europeu". Na própria obra de Bastide, a questão central talvez seja justamente a da famosa "integração do negro na sociedade de classes". Tudo se passa então, como acontece frequentemente demais na antropologia, como se o ponto de vista do Estado, com seus problemas de nation building, levasse a melhor, impondo essa espécie de certeza, que parece durar até hoje, de que a única identidade legítima é a identidade nacional. 
É claro que a estatização, ou o branqueamento, da relação afroindígena não marcou apenas as investigações acadêmicas. Como bem se sabe, no caso brasileiro, assim como em muitos outros, o encontro e a relação afroindígena foram devidamente submetidos à "sociedade dos brancos" e pensados na forma daquilo que se convencionou chamar "mito das três raças". Mito, inútil lembrar, que elabora, justamente, a "contribuição" de cada uma dessas "raças" para a constituição da "nação brasileira", mas segundo uma lógica e um processo em que o vértice superior do triângulo das raças só pode ser, claro, encabeçado pelos brancos.

Quanto à antropologia, em especial a brasileira, a questão que se coloca é bem simples. Por que, afinal de contas, a proximidade entre ameríndios e afro-americanos - ou seja, o fato inelutável de que, ao longo dos séculos, e ainda hoje, eles não puderam deixar de estabelecer e de pensar suas relações - sempre esteve acompanhada de um afastamento teórico que faz com que dessa relação não saibamos quase nada ou saibamos apenas o menos interessante? Pois é esse afastamento que fez com que esses coletivos e suas cosmopolíticas tenham sido tão raramente estudados e/ou analisados em conjunto, preferindo-se, em geral, aproximações teóricas com outras terras, a Melanésia, a Sibéria ou mesmo a própria África. Contra essa pobreza antropológica muitas etnografias recentes vêm mostrando a riqueza com a qual a relação afroindígena é pensada pelos coletivos nela interessados e que não encontra nenhum paralelo digno na reflexão acadêmica.

O primeiro passo, sem dúvida, consistiria em um movimento para libertar a relação afroindígena da dominação e do ofuscamento teórico-ideológicos produzidos pela presença dessa variável "maior", os "brancos", o que significa tentar praticar aquilo que, seguindo o exemplo do autor de teatro Carmelo Bene, Deleuze denominou operação de "minoração": a subtração da variável majoritária dominante de uma trama faz com que esta possa se desenvolver de um modo completamente diferente, atualizando as virtualidades bloqueadas pela variável dominante e permitindo reescrever toda a trama (Deleuze \& Bene 1979:97-101). Em poucas palavras e grosso modo: como ficaria o mito das três raças se dele suprimíssemos não o fato histórico, político e intelectual do encontro, mas o vértice "maior" do triângulo, os "brancos"? Como apareceriam afros e indígenas sem este elemento sobrecodificador?

Antes, contudo, como costuma dizer Isabelle Stengers, talvez seja preciso ir um pouco mais devagar e começar sublinhando os riscos desse empreendimento. Para isso, é necessário deixar claro as imagens que eu não gostaria que o termo afroindígena evocasse, os clichês que eu não gostaria que ele desencadeasse. O ponto central é que não se trata de pensar a 
relação afroindígena nem de um ponto de vista genético (no sentido amplo do termo), nem a partir de um modelo tipológico. Não se trata de gênese porque não se trata de determinar o que seria afro, o que seria indígena e o que seria resultado de sua mistura — ou, eventualmente, o que não seria nem uma coisa nem outra. E isso seja em um sentido propriamente biológico ou genealógico, seja em sentido cultural, social etc. Não se trata, portanto, de um problema de identidade, muitas vezes, aliás, confundido com o das origens, o que pode não ser tão fácil quanto parece, porque a primeira coisa que somos tentados a fazer toda vez que nos deparamos com situações "afroindígenas" são exatamente essas triagens que eu gostaria de evitar.

Por outro lado, não é nada incomum que, ao evitar o fogo da gênese, os antropólogos caiam na frigideira da tipologia, onde, fingindo fazer abstração das conexões genéticas, acabam chegando exatamente no mesmo lugar. Estabelecer um tipo (ideal ou não, pouco importa) afro puro, um tipo indígena puro, e quantos tipos intermediários forem não é, de modo algum, o que importa. Nem os modelos historicistas, nem os estrutural-funcionalistas, em suas variantes explícitas ou mais ou menos disfarçadas, possuem qualquer utilidade aqui. Pois não se trata, na verdade, de identificar e/ou contrastar aspectos históricos, sociais ou culturais em si, mas princípios e funcionamentos que podem ser denominados ameríndios e afro-americanos em função das condições objetivas de seu encontro, o que significa que não são traços, aspectos ou agrupamentos culturais que devem ser comparados, mas os princípios a eles imanentes.

Observemos, igualmente, que esse enfoque privilegiando comparações e interações afroindígenas poderia também conduzir à produção de contribuições inovadoras para o campo das chamadas "relações interétnicas". Sabe-se bem como a história de diversos países americanos foi contada, em uma chave ideológica, com ênfase sobre o encontro das "três raças" que teriam harmoniosamente constituído a nação. É supérfluo denunciar o caráter mistificador deste tipo de narrativa, mas talvez valha a pena assinalar que ela reelabora um fenômeno que indubitavelmente não pôde deixar de ter ocorrido. Como também escreveu Roger Bastide (1960:20), "não são as civilizações que estão em contato, mas os homens" — ou as pessoas - e cabe a nós tentar descobrir e pensar o que aconteceu e ainda acontece nesses encontros - que, aliás, não são apenas entre pessoas, mas também com deuses, objetos, lugares, músicas, danças etc. Por outro lado, como vimos, nunca se enfatizou suficientemente que a natureza das relações que unem os vértices do triângulo das "três raças" não pode ser a mesma, caso se considerem as relações entre dominantes e dominados ou apenas aquelas entre os segundos. 
Ora, essas relações se estabelecem entre elaborações que se situam em diversas dimensões: sociológicas, mitológicas, religiosas, epistemológicas, ontológicas, cosmopolíticas. Trata-se, em última instância, de mapear as premissas imanentes aos discursos nativos, extraindo consequências teórico-experimentais efetivas das críticas antropológicas que, ao longo dos últimos cem anos, vêm insistindo na impossibilidade de determinação de qualquer "grande divisor" capaz de distinguir substantivamente os coletivos humanos entre si. Impossibilidade tanto mais evidente quanto as transformações empíricas em curso na paisagem sociocultural do planeta mostram a aceleração simultânea dos processos aparentemente contraditórios de convergência e divergência, mimetismo e diferenciação, dissolução e endurecimento das fronteiras (tanto objetivas como subjetivas) entre os coletivos. Estas dificuldades devem ser levadas a sério, permitindo a elaboração de abordagens alternativas que afirmem a fecundidade epistemológica de tais impasses e os situem no coração da produção antropológica.

Se quisermos escapar do clichê antropológico que quer nos prender à mera determinação de variedades culturais e universais humanas, o que deve ser visado é o mapeamento das premissas epistemológicas, ontológicas, cosmopolíticas imanentes aos discursos nativos, o que, de imediato, revela que não há nenhuma razão para confinar o procedimento a uma área etnográfica ou a um "tipo" de sociedade. Trata-se de explorar — à luz de contribuições teóricas recentes em torno da "antropologia simétrica" e dos "grandes divisores" - a questão da potencialidade teórica e/ou heurística dessas distinções entre sociedades, e a de sua superação. E trata-se em seguida de estimular um diálogo que, retomando a melhor tradição antropológica, confronte as contribuições específicas das pesquisas realizadas em sociedades "indígenas" e "complexas", a fim de que possam se fecundar reciprocamente, escapando do aprisionamento em círculos restritos de especialistas e das excessivas concessões aos clichês dominantes.

Isto significa, sobretudo, evitar o risco de simplesmente reproduzir, num estilo talvez mais sofisticado, os clássicos debates em torno do chamado sincretismo religioso e, assim, isolar traços de culturas originais puras que teriam se mesclado formando cada manifestação sociocultural específica. Ao contrário, o ponto é a delimitação e o contraste de princípios cosmológicos de matriz ameríndia ou africana, sem perder de vista nem sua especificidade, nem as condições históricas de seu encontro. Ou, em outros termos, trata-se de tentar colocar em diálogo produções etnográficas e reflexões teóricas oriundas de dois domínios tradicionalmente separados da antropologia, na esperança de que, por meio desse diálogo, seja possível trazer à luz novas conexões - e novas distinções - entre eles. 
Se quiséssemos seguir um modelo, poderíamos denominá-lo, talvez, transformacional, em um sentido análogo, mas não idêntico ao que o termo possui nas Mitológicas, onde Lévi-Strauss (1964-1971) não descarta as conexões históricas, genéticas e mesmo tipológicas entre ameríndios, mas desenvolve um procedimento que visa contornar e superar essas obviedades. Seguindo exemplos mais recentes, como o de Marilyn Strathern (1988) na Melanésia, talvez seja possível tratar desse modo materiais afro-americanos em conexão com materiais ameríndios.

Por outro lado, essas "transformações" também devem ser pensadas no sentido deleuziano sugerido acima (o de um procedimento de minoração por extração do elemento dominante) e em um sentido guattariano, porque as conexões que se pretende estabelecer não são nem horizontais, nem verticais, mas transversais. Ou seja, não se trata de encarar as variações nem como variedades irredutíveis umas às outras, nem como emanações de um universal qualquer conectando entidades homogêneas: as conexões se dão entre heterogêneos enquanto heterogêneos, as relações se dão entre diferenças enquanto diferenças, como lembra Guattari (1992) ao falar de heterogênese, conceito que tem como premissa fundamental a hipótese de que o diferencial não pode ser encarado como mera negação e/ou oposição, uma vez que ele é sobretudo da ordem da criação ou da criatividade.

Isto significa também, diga-se de passagem, que talvez seja preciso livrar a comparação levistraussiana da noção de estrutura, ou seja, abandonar a ideia da realidade como um conjunto de atualizações parciais localmente moduladas de um conjunto de possíveis que, uma vez não atualizados, são destinados a uma espécie de tranquila inexistência. Como se sabe, Deleuze e Guattari propuseram uma perspectiva diferente sobre este ponto ao introduzirem o conceito de virtual-real para se opor justamente à dupla noção estruturalista do possível e do atual. Falar em virtual-real significa supor que o que não está manifestamente atualizado continua a existir de alguma forma, ou antes, continua a funcionar, podendo sempre ser recolocado em jogo. Mais que um método transformacional, tratar-se-ia talvez de algo como uma perspectiva transformacional, na qual ontologia se torna sinônimo de diferença, e epistemologia, de ética. Porque não há nenhuma razão, a não ser moral e política, para subordinar a diferença à identidade ou a ética à epistemologia.

É preciso, pois, proceder com cautela, mas o esforço para colocar em diálogo materiais ameríndios e afro-americanos tão heterogêneos permite desde já entrever ao menos três tipos de elaboração. Em primeiro lugar, contextos nos quais os próprios coletivos se definem, mais ou menos diretamente, como afroindígenas. 
Em segundo lugar, temos as situações em que coletivos autodefinidos como ameríndios e coletivos autodefinidos como afro-americanos se encontram e interagem efetivamente - mesmo que, como costuma acontecer frequentemente, esses encontros e essas interações possam ser tão codificados que correm o risco de passar despercebidos.

Enfim, terceira possibilidade: aquela em que, de alguma forma, o próprio analista se faz, por assim dizer, afroindígena, promovendo e mesmo provocando o encontro de materiais tradicionalmente destinados à incomunicabilidade, devidamente fechados em seus nichos acadêmicos de proteção. Não é difícil imaginar como esse procedimento poderia enriquecer debates tradicionais confrontando temáticas classicamente tidas como "indígenas" (totemismo, xamanismo, multiplicidade de espíritos...) com outras, tidas por "afro-americanas" (sacrifício, possessão, panteões hierarquizados de divindades e assim por diante) e que, no entanto, todos sabemos poderem ser encontradas, de acordo com distintas transformações, dos dois lados do divisor.

Trata-se, assim, de proceder a um confronto entre cosmopolíticas e coletivos em princípio heterogêneos que poderia servir para seu esclarecimento mútuo, evitando o evolucionismo no plano histórico, o dualismo no plano ontológico, e o maniqueísmo no plano ético. Essas cosmopolíticas e esses coletivos devem, assim, ser tomados no que apresentam de desconhecido, incerteza, indeterminação, não a partir daquilo que sabemos ou acreditamos saber a seu respeito. Não se trata tampouco de supor algum tipo de unidade ou identidade lá onde se via apenas diferença; trata-se, seguindo o que Deleuze e Guattari chamam "método diferencial", de buscar e analisar com cuidado as "distinções abstratas" a fim de que as "misturas concretas" se tornem mais inteligíveis. Em outros termos, é preciso distinguir analiticamente bem para melhor entender as alianças e os agenciamentos efetivos que produzem as misturas concretas.

Isto não significa, contudo, abrir mão de um ponto essencial, o fato de que, como escreveu em alguma parte Lévi-Strauss, a antropologia é uma ciência empírica e que, nela, o material empírico deve guiar as problematizações e as conceptualizações. Com o adendo de que esse material empírico envolve necessariamente o que as pessoas pensam e têm a dizer sobre o que acontece com elas mesmas e com os outros, uma vez que a antropologia deve estar sempre subordinada à palavra nativa, de tal modo que seu discurso não tenha privilégio algum em face daqueles com quem trabalha. Nesse sentido, o melhor procedimento inicial talvez seja tomar o termo "afroindígena" nos sentidos em que as próprias pessoas que gostam de pensar a si mesmas como afroindígenas o utilizam. Ou o que é a mesma coisa, sublinhar que o termo "afroindígena" tem, ou pode ser tomado como tendo, uma origem afroindígena. 
Desse modo, eu gostaria de utilizar algumas reflexões nativas para apresentar um pouco melhor o que estou propondo. Tentarei fazê-lo a partir da maneira pela qual dois coletivos distintos elaboram a relação afroindígena, abrindo assim, talvez, a possibilidade de uma reflexão antropológica sobre este tema. Esses dois coletivos, aparentemente muito heterogêneos, vivem no extremo-sul e no sul baianos; o primeiro - os membros do movimento cultural da cidade de Caravelas, estudados por Cecília Mello $(2003,2010)$ se pensa decididamente como afroindígena; o segundo, os Tupinambá da Serra do Padeiro, estudados, entre outros, por Helen Ubinger (2012) — se define resolutamente como indígena.

Quando foram apresentados pela primeira vez, há mais de dez anos, nem o material etnográfico, nem a análise empírica e a teórica de Cecília Mello se acomodavam muito bem a um certo clichê que parecia dominar o pensamento antropológico, mas que, tudo indica, é cada vez mais difícil de sustentar: a quase certeza de que não temos nada de importante a aprender com as pessoas com quem convivemos durante nossas pesquisas, seja porque elas realmente não seriam capazes de nos ensinar nada, seja porque aquilo que elas eventualmente nos ensinam é de curto alcance, limitado ao contexto paroquial em que vivem.

As pessoas que Cecília estudou em Caravelas criaram e fazem parte de um bloco de carnaval (o Umbandaum), de um "Movimento Cultural" (o Arte Manha) e de um Grupo Afroindígena de Antropologia Cultural - todos os termos são deles. Neles, desenvolvem uma série de atividades que visam "resgatar" a memória afroindígena, usando para isso formas de expressão artísticas, que envolvem a escultura, os entalhes em madeira, a pintura, mas também o teatro e a dança. Além disso, e este ponto é fundamental, sua arte resulta de pesquisas e debates coletivos sobre suas origens afroindígenas e suas formas de expressão. As atividades do movimento se concretizam também no Umbandaum, definido como "bloco-manifestação política" que, desde 1989, ocupa as ruas de Caravelas no sábado de carnaval, apresentando orixás, caboclos e personalidades históricas marginalizadas da história baiana. Esse desfile é definido como o que Cecília (2013) denomina "um teatro-performance, em que os componentes incorporam personagens e traduzem suas características através de expressões faciais e corporais".

As mesmas pessoas que fazem o movimento cultural e o bloco são, ademais, filiadas ao Partido dos Trabalhadores e desenvolvem intensa militância político-eleitoral - tendo alguns se candidatado por diversas vezes a cargos eletivos e mesmo ocupado algumas secretarias municipais. Além disso, boa parte de seu tempo é tomado pela elaboração de belíssimas obras de arte, de esculturas a móveis chamados "rústicos", criadas a partir da técnica 
que denominam "reaproveitamento da madeira", ou seja, a utilização de madeira considerada "morta", encontrada nas matas que ainda sobrevivem aos eucaliptais que infestam a região, madeira que, devidamente tratada, adquire uma espécie de nova vida.

O ponto essencial aqui é que essas pessoas não apenas se pensam (no sentido forte da palavra) como "afroindígenas", como desenvolvem uma série de complexas reflexões sobre essa expressão e sobre a sua própria situação no mundo. Em lugar de pretender saber de antemão e "revelar" o que seus amigos estariam "realmente" querendo dizer ao se afirmarem afroindígenas, Cecília preferiu seguir de modo detalhado e profundo o que eles efetivamente dizem, fazem e pensam a respeito de si mesmos, dos outros e dos mundos de que participam. Porque a necessidade de que os outros pensem - para usar uma expressão de Deleuze retomada por Stengers — não significa, é claro, que devamos obrigá-los a pensar, muito menos tentar "esclarecê-los" ou, no limite, lamentar que não pensem. A necessidade de que os outros pensem é uma abertura para seu pensamento, a aceitação de que as pessoas realmente pensam, mesmo, ou principalmente, quando pensam diferente de nós. Desterritorialização do pensamento próprio por meio do pensamento de outrem, espécie de participação, discurso livre indireto, única justificativa, talvez, para a prática antropológica.

Em lugar de ceder à tentação de julgar se seus amigos eram "de fato" negros, índios, mestiços, pobres, ou o que quer que seja, a antropóloga aprendeu que "afroindígena" não precisa necessariamente ser da ordem da identidade, mas pode ser pensado como algo que se torna, que se transforma em outra coisa diferente do que era, mas que, de algum modo, conserva uma memória do que se foi - como um devir, portanto.

Cecília aprendeu também que o termo "afroindígena" quer dizer muitas coisas: um modo de descendência, sem dúvida, mas também uma origem explicitamente reconhecida como mítica e uma forma de expressão artística, ou seja, criativa; que não se trata da simples justaposição de influências ou formas distintas e irredutíveis, mas de uma terceira forma, com características próprias e ao mesmo tempo comuns às outras; que a relação entre afros e indígenas não é pensada apenas como de proximidade entre mundos paralelos, mas como uma interseção entre esses mundos, como um encontro entre indígenas e africanos. Que o encontro tenha sido real ou não - ou que ele esteja sendo explorado em sua realidade história ou não - pouco importa. O que realmente importa é a virtualidade desse encontro, aquilo que ele poderia ter produzido e que, por isso mesmo, ainda pode sê-lo. Finalmente, Cecília também aprendeu que o conceito foi elaborado com as mesmas técnicas utilizadas na criação das obras de arte que o grupo produz. 
Vê-se, assim, que as relações afroindígenas são pensadas, simultaneamente, na chave da filiação e na da aliança, extensivas e intensivas ao mesmo tempo; que tanto uma quanto a outra são encaradas em sua molaridade histórica e em sua molecularidade criativa. O afroindígena é uma linha de fuga minoritária não apenas em relação à variável majoritária dominante "brancos", mas também em relação à captura que sempre ameaça as linhas de fuga: o rebatimento do devir em uma identidade ou mesmo em um pertencimento - negro, índio como minoria em lugar de devir-minoritário ou menor.

É nesse sentido que o conceito de afroindígena é criado em Caravelas a partir dos mesmos procedimentos utilizados para criar qualquer obra de arte, ou seja, a partir dessa técnica que os artistas chamam de "reaproveitamento" ou "ressuscitamento", técnica que opera por meio da reatualização de virtualidades reprimidas pela história. Uma árvore derrubada ou uma dança esquecida preservam potências vitais que o artista e o militante podem desencadear. Trata-se, assim, de uma espécie de bricolage das experiências históricas vividas de diferentes maneiras pelos membros do grupo como afros e como indígenas, ou seja, como dominados. Do mesmo modo que na "madeira morta" uma nova vida pode ser encontrada, nas experiências de resistência à dominação uma nova força pode sempre ser despertada.

Se para os Maia do México contemporâneo, como mostrou Pedro Pitarch (2013), a coexistência de narrativas indígenas e europeias é um modo de não permitir a incorporação da lógica europeia na própria narrativa indígena, no caso de Caravelas tudo se passa como se fosse a articulação das narrativas afro e indígena que produz esse efeito de evitar a incorporação da lógica dominante, o que não significa que aquilo que os Maia obtêm a partir de uma evitação rigorosa de qualquer mistura seja feito pelos afroindígenas simplesmente "misturando" as coisas.

Já há algum tempo, José Carlos dos Anjos (2006) nos revelou tudo o que teríamos a ganhar abandonando os clichês dominantes da miscigenação, da mestiçagem ou do sincretismo em benefício de imagens oriundas de nossos próprios campos empíricos de investigação. Assim, a ideia de "linha cruzada", presente em praticamente todas as religiões de matriz africana no Brasil, permite pensar um espaço de agenciamento de diferenças enquanto diferenças, sem a necessidade de pressupor nenhum tipo de síntese ou fusão. As diferenças são intensidades que nada têm a ver com uma lógica da assimilação, mas sim com a da organização de forças, que envolve a modulação analógica (contra a escolha digital) dos fluxos e de seus cortes, bem como o estabelecimento de conexões e disjunções. Esse modelo heterogenético apoiado nas variações contínuas permite opor termo a termo mestiçagem e sincretismo, de um lado, contramestiçagem e composição (no sentido artístico do termo), de outro. 
Porque em última análise é do mito das três raças que os afroindígenas de Caravelas estão tentando se livrar. E, se o fazem, é porque sabem muito bem que os mitos das classes dominantes têm o mau costume de produzir efeitos muito reais. Nesse sentido, sua elaboração do afroindigenismo tem igualmente uma dimensão mítica. Aqui, entretanto, temos que livrar o conceito de suas dimensões representacionais ou mesmo estruturais. Como escreveram Deleuze e Guattari (1972:185), o mito não é "uma representação transposta ou mesmo invertida das relações reais em extensão"; ele, ao contrário, "determina, conforme o pensamento e a prática indígenas, as condições intensivas do sistema"; ou, em outras palavras, o mito "não é expressivo, mas condicionante". O problema é de agenciamento, não de representação.

Se a bricolage, como postulou Lévi-Strauss (1962), corresponde, no plano da atividade prática, ao mito da atividade especulativa, a mesma passagem do expressivo ao condicionante poderia ser transposta para essa noção. O "reaproveitamento", ou "ressuscitamento", é uma forma de resistência, e a criação de novas condições e condicionantes faz parte inevitável de toda luta política.

O afroindígena pode aparecer, assim, como uma espécie de perspectiva. Perspectiva que não é tanto a da oposição simples entre afroindígena, de um lado, e brancos, de outro - o que reconduziria inevitavelmente a uma captura pela forma-identidade - mas sim uma perspectiva estabelecida a partir da oposição mesmo entre afro e indígena, oposição que, evidentemente, é de natureza muito distinta daquela entre afro e/ou indígena, de um lado, e branco, de outro.

Trata-se - esta talvez seja a hipótese mais forte que eu gostaria de levantar - de um processo que poderíamos denominar "contramestiçagem". Não no sentido de uma recusa da mistura em nome de uma pureza qualquer, mas no da abertura para o caráter analógico, e não digital, e para o elemento de indeterminação que qualquer processo de mistura comporta.

Em certo sentido, o desafio colocado pela exploração antropológica da noção de afroindígena — que aparece ou reaparece hoje em tantas partes bem como de seus correlatos, não é mais do que a tentativa de elaborar em chave acadêmica aquilo que os militantes afroindígenas de Caravelas, assim como muitos outros, expuseram em chave existencial.

A quase $400 \mathrm{~km}$ ao norte de Caravelas, e a cerca de $50 \mathrm{~km}$ do litoral, fica a cidade de Buerarema, parte da antiga grande região cacaueira baiana. E a pouco menos de $20 \mathrm{~km}$ do centro de Buerarema fica a Serra do Padeiro, onde vivem hoje quase mil tupinambás. Eles fazem parte de um grupo mais abrangente que inclui os Tupinambá de Olivença (que vivem mais perto do litoral) e, como seus vizinhos, lutam há pelo menos vinte anos pela criação 
de sua terra indígena (sobre o que se segue, ver principalmente Ubinger [2012], também Macêdo [2007] e Couto [2008]).

A história dos Tupinambá dessa região se parece muito com a de inúmeros grupos indígenas do nordeste brasileiro - e hoje também de outras regiões. Grosso modo, essa história é por eles dividida entre um grande período que vai do século XVI ao XIX (marcado por sua redução em missões jesuítas em conjunto com outros grupos indígenas e, depois, pela ocupação de certos territórios), seguido, a partir do início do século $\mathrm{XX}$, por períodos mais curtos de invasão, expulsão, revolta, dispersão, submersão e retomada. Esta não é a ocasião para nos determos nesse intrincado processo e no complexo modo como é pensado e narrado pelos envolvidos. Basta observar que os Tupinambá não supõem que tenham deixado de existir enquanto indígenas em nenhum momento, e que pensam as alianças e a submersão a que se viram obrigados a praticar como meios de luta para garantir a sua existência.

Desse modo, não veem nenhum problema em reconhecer que são "misturados". No entanto, e ao contrário do que vimos ocorrer em Caravelas, a expressão afroindígena parece não fazer muito sentido na Serra do Padeiro, uma vez que a mistura não anula o fato de que são, sempre foram e pretendem permanecer indígenas. Tudo se passa de modo semelhante àquele que foi descrito pela primeira vez, em 1991, por Peter Gow para os Piro da Amazônia peruana: o fato de que a diferença entre pessoas pode ser introjetada em cada uma não anula o fato de que, coletivamente, podem seguir sendo o que sempre foram. Parafraseando uma comunicação oral de Pedro Pitarch para o caso dos Maia mexicanos, os Tupinambá da Serra do Padeiro não são os "descendentes" dos antigos Tupinambá: eles são aqueles Tupinambá que foram capazes de sobreviver a uma experiência histórica devastadora.

De seu próprio ponto de vista, o ponto central dessa articulação entre identidade e diferença, continuidade e descontinuidade parece se situar no plano cosmológico. Conhecidos pelo culto que prestam aos encantados, continuam a ver suas práticas religiosas sendo usadas para negar a eles o direito a terra, sob o argumento de que assim como fenotipicamente eles não parecem índios, sua religião estaria mais próxima das religiões de matriz africana do que de práticas indígenas.

Como se sabe, por "encantado" entende-se, em praticamente todo o Brasil, do oeste amazônico ao litoral nordestino e do extremo norte do país a Minas Gerais, um conjunto de seres espirituais que assumem características semelhantes e diferentes nas diversas práticas religiosas em que aparecem. Denominados em muitas partes "caboclos", esses encantados se caracterizam, em geral, por não se confundirem com as divindades propriamente ditas e, ao mesmo tempo, por apresentarem algum tipo de afastamento significativo 
em relação aos antepassados e aos espíritos de mortos em geral. Ainda que isso não ocorra em todas as partes, os encantados costumam ser pensados como "vivos", seja no sentido de que são seres que passaram deste plano da existência para outro sem conhecer a experiência da morte, seja no sentido de que sempre existiram, habitaram e protegeram determinado território.

É bem nesta última acepção que os Tupinambá da Serra do Padeiro definem os seus encantados - que eles ocasionalmente chamam de "caboclos", termo igualmente utilizado como sinônimo de índios. Os encantados são os "donos da terra", essa terra que foi transformada em um "território de sangue" e que é preciso agora "curar", transformando-a em uma "Terra sem Males". Esta será a nova forma da vingança tupinambá, não mais a partir de um "derrame de sangue", mas justamente da cura de um território doente de sangue. Para isso, são necessárias as "retomadas" das terras, da cultura, da vida. Retomadas que devem ser entendidas literalmente no sentido proposto por Isabelle Stengers para a noção de "reclaim": não simplesmente lamentar o que se perdeu na nostalgia de um retorno a um tempo passado, mas sim recuperar e conquistar ao mesmo tempo, "tornar-se capaz de habitar de novo as zonas de experiência devastadas" (Pignarre \& Stengers 2005:185).

O modo como os Tupinambá da Serra do Padeiro narram os começos de seu culto aos encantados é impressionante e constitui um dos condicionantes de suas práticas e representações. Um migrante do sertão baiano acaba parando na Serra e se casando com uma nativa. Um de seus filhos experimenta crises de dor ou mesmo de "loucura". Seu pai decide levá-lo para a mais famosa mãe de santo da Bahia, Mãe Menininha do Gantois, sua parente distante. Em Salvador, a poderosa mãe de santo se dá conta de que não pode curá-lo porque ele já possui o poder da cura. E que a única solução é "cumprir sua sentença", ou seja, voltar para a Serra e começar a curar as pessoas. De volta, o primeiro pajé tupinambá contemporâneo cura primeiro a si mesmo e em seguida outras pessoas. Em seus sonhos, descobre pessoas com o mesmo dom, capazes de acolher os encantados, e dá início a seu culto. Começa a acolher um encantado específico, o Caboclo Tupinambá, que avisa que "essa terra vai voltar a ser uma aldeia indígena", e anuncia a missão de retomada do território indígena. Nessa retomada, humanos e encantados são parceiros: os segundos seguem sempre na frente das ocupações territoriais e conduzem os primeiros na retomada da cultura.

Quando confrontados com a acusação de que suas práticas religiosas não seriam realmente indígenas, mas "misturadas" ou mesmo de origem africana, os Tupinambá da Serra do Padeiro sabem exatamente o que dizer. Como afirma Célia, irmã do cacique Babau e grande pensadora, "o candomblé é bom pra gente usar" (Ubinger 2012:149). Continuo a citá-la: 
A gente não discrimina, sabemos que algumas das entidades dos negros são do bem. Mas se eles não combinam, a gente não trabalha com eles, nós não trabalhamos com as entidades negras, mas algumas sim, pois elas ajudam. Porque havia muito contato entre as culturas (Ubinger 2012:135).

Ora, essa visão pragmática, no sentido filosoficamente mais profundo do termo, também pode ser aplicada às religiões dos brancos. Como diz Célia, orações católicas, por exemplo, são utilizadas pelos Tupinambá, mesmo que eles de modo algum sejam cristãos, porque - e sigo citando-a:

Nós fomos catequizados. Aí nós usamos o que era bom ou tinha mais força da religião do outro e adaptamos às nossas práticas e crenças. Mas continuamos fazendo nossos rituais e tendo fé nas nossas crenças, só que adaptamos, usando o que era útil ou bom do homem branco (Ubinger 2012:135).

Tão longe, tão perto dos afroindígenas de Caravelas. A relação afroindígena segue sendo o modo pelo qual se pode resistir aos brancos, mesmo que, neste caso, seja preciso manter a separação interna entre afro e indígena, de algum modo "eclipsada" pelos militantes de Caravelas. Índios até o século XIX, os Tupinambá se veem obrigados a "submergir" para não serem mortos - um pouco como seus encantados, que passam de um plano a outro sem conhecer a experiência da morte. Nessa submersão, tanto eles quanto seus encantados se metamorfoseiam em "caboclos", capazes de sobreviver em alguns nichos até poderem reemergir neste mundo como índios e encantados a fim de retomarem o que é seu.

Não se trata aqui ainda de tirar muitas conclusões da justaposição etnográfica e conceitual que apenas esbocei a partir dos belos trabalhos de Cecília Mello e Helen Ubinger. Limito-me a observar que esse confronto pode ser estendido a outras etnografias e teorias nativas na direção da elaboração de teorias etnográficas - para voltar ao conceito malinowskiano que redescobri em meu trabalho sobre política - do que estou chamando provisoriamente (contra)mestiçagem.

De todo modo, essas teorias etnográficas devem necessariamente se apoiar em teorias nativas, e tudo indica que estas nunca deixam de opor, ou de distinguir, o cruzamento, a parcialidade, a heterogênese, a modulação analógica, as intensidades, as variações contínuas, a composição e a contramestiçagem aos clichês dominantes da síntese, da totalidade, da miscigenação, da identificação por contraste, dos interesses, da lógica da assimilação, da fusão e da mestiçagem e/ou sincretismo.

É nesse sentido que creio que a relação afroindígena possui um alto potencial de desestabilização do nosso pensamento e que, por isso mesmo, 
deve estar no coração de uma antropologia que encara as diferenças, que leva a sério o que as pessoas pensam, que é capaz de se manter afastada dos clichês que nos assolam e, assim, pensar diferente.

Para terminar, queria apenas justificar meu título, no qual fiz o que sempre aconselho meus estudantes a não fazerem - a utilização literal de uma expressão nativa seguida de um rebuscado subtítulo. Desta vez, contudo, não fui capaz de resistir à força do episódio que me foi narrado por outra ex-aluna que, como eu, fez sua pesquisa de campo em Ilhéus. No mercado local de artesanato, Ana Cláudia Cruz da Silva vê um turista comprando artesanato indígena de um vendedor que se apresenta como tupinambá. Um pouco cético, o turista pergunta se ele é mesmo índio; ele responde que sim, que é índio; o turista insiste na dúvida, suspeitando, sem dúvida, de uma ascendência negra; o índio confirma que é tupinambá; o turista ainda argumenta: "mas você não parece índio!". E a resposta: "O que o senhor queria? São quinhentos anos de contato". 


\section{Referências bibliográficas}

ANJOS, José Carlos Gomes dos. 2006. Território da linha cruzada: a cosmopolítica afro-brasileira. Porto Alegre: UFRGS.

BASTIDE, Roger. 1960. Les religions africaines au Brèsil. Paris: PUF.

_ 1976 [1973]. "La rencontre des dieux africains et des esprits indiens". AfroAsia, 12:31-45.

BORGES, Jorge Luis. 1974 [1935]. “El atroz redentor Lazarus Morell". In: Obra completa 1923-1972. Buenos Aires: Emecé Editores.

COUTO, Patrícia Navarro de Almeida. 2008. Morada dos encantados: identidade e religiosidade entre os tupinambá da Serra do Padeiro - Buerarema, BA. Dissertação de Mestrado, Salvador, UFBA.

DELEUZE, Gilles \& BENE, Carmelo. 1979. Superpositions. Paris: Minuit.

DELEUZE, Gilles \& GUATTARI, Félix. 1972. L'Anti-Oedipe: capitalisme et schizofrénie. Paris: Minuit.

GOLDMAN, Marcio. 2015. "A relação afroindígena". Cadernos de Campo, 23 (no prelo).

GUATTARI, Félix. 1992. Chaosmose. Paris: Galilée.

. 1993. "La pulsion, la psychose et les quatre petits foncteurs". Revue Chimères, 20:113-122.

LÉVI-STRAUSS, Claude. 1962. La pensée sauvage. Paris: Plon.

_.1964-1971. Mythologiques (4 vols.). Paris: Plon.

LOSONCZY, Anne-Marie. 1997. Les saints et la forêt: rituel société et figures de l'échange entre noirs et indiens emberá. Paris: L'Harmattan.

MACÊDO, Ulla. 2007. A "dona do corpo": um olhar sobre a reprodução entre os Tupinambá da Serra - BA. Dissertação de Mestrado, Salvador, UFBA.
MEllo, Cecília Campello do Amaral. 2003. Obras de arte e conceitos: cultura e antropologia do ponto de vista de um grupo afro-indígena do sul da Bahia. Dissertação de Mestrado, Rio de Janeiro, PPGAS-Museu Nacional. . 2010. Política, meio ambiente e arte: percursos de um movimento cultural do extremo sul da Bahia (2002-2009). Tese de Doutorado, Rio de Janeiro, PPGAS-Museu Nacional. . 2013. "Irradiação e bricolagem do ponto de vista de um movimento cultural afroindígena". Cosmos e Contexto: Revista Eletrônica de Cosmologia e Cultura, 18. Disponível em: http:// www.cosmosecontexto.org.br/?p=2292 Acesso em: 23/11/2015.

PIGNARRE, Philippe \& STENGERS, Isabelle. 2005. La sorcellerie capitaliste. Paris: La Découverte.

PITARCH, Pedro. 2013. La cara oculta del pliegue. Ensayos de antropología indígena. México: Artes de México/ Conaculta.

STRATHERN, Marilyn. 1988. The gender of the gift: problems with women and problems with society in Melanesia. Berkeley: University of California Press. UBINGER, Helen Catalina. 2012. Os tupinambá da Serra do Padeiro: religiosidade e territorialidade na luta pela terra indígena. Dissertação de Mestrado, Salvador, UFBA. 